\title{
Robotic vs. laparoscopic major hepatectomy
}

\author{
loannis A. Ziogas', Samer Tohme², David A. Geller² \\ 'Department of Surgery, Division of Hepatobiliary Surgery and Liver Transplantation, Vanderbilt University Medical Center, \\ Nashville, TN 37232, USA. \\ 2Department of Surgery, Division of Hepatobiliary and Pancreatic Surgery, University of Pittsburgh Medical Center, Pittsburgh, \\ PA 15260, USA.
}

Correspondence to: Prof. David A. Geller, Department of Surgery, Division of Hepatobiliary and Pancreatic Surgery, University of Pittsburgh Medical Center, Montefiore 7 South, 3459 Fifth Avenue, Pittsburgh, PA 15260, USA. E-mail: gellerda@upmc.edu

How to cite this article: Ziogas IA, Tohme S, Geller DA. Robotic vs. laparoscopic major hepatectomy. Mini-invasive Surg 2020;4:69. http://dx.doi.org/10.20517/2574-1225.2020.63

Received: 19 Jun 2020 First Decision: 31 Aug 2020 Revised: 31 Aug 2020 Accepted: 3 Sep 2020 Published: 12 Oct 2020

Academic Editor: Giulio Belli Copy Editor: Cai-Hong Wang Production Editor: Jing Yu

\begin{abstract}
The introduction of laparoscopic technology and surgical robots in hepatobiliary surgery in the 1990s and 2000s, respectively, has dramatically revolutionized the field. Even though laparoscopic and robotic major hepatectomy was slower to adopt compared to minimally-invasive minor hepatectomy, the number of major hepatectomies performed with both approaches worldwide has significantly increased and is still rising. Despite the few comparative studies between laparoscopic and robotic major hepatectomy, most studies are focused on describing the procedures or reporting the outcomes of each method, either separately, or mixed with minor hepatectomies. Based on the available data, the direct comparison between the two techniques has shown that when robotic major hepatectomy is performed by experienced hepatobiliary surgeons in high-volume centers, it can lead to similar operating times, estimated blood loss, hospital length of stay, complication and mortality rates compared to its laparoscopic counterpart. The likelihood of achieving a margin-negative resection in cancer patients, as well as long-term disease-free and overall-survival are comparable between the groups. However, broader adoption of the robotic approach might be a hurdle in low-volume centers due to the high fixed capital and annual maintenance cost of the surgical robot.
\end{abstract}

Keywords: Hepatectomy, liver resection, major hepatectomy, laparoscopic, robotic, minimally-invasive

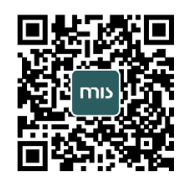




\section{INTRODUCTION}

The introduction of minimally-invasive technology in the approach of liver disorders in the early $1990 \mathrm{~s}$ has since revolutionized the field of liver surgery ${ }^{[1-5]}$. Laparoscopic liver surgery does not only include pure laparoscopy, but also hand-assisted laparoscopic, as well as hybrid approaches, where the initial part of the procedure (i.e., liver mobilization, early dissection) is done laparoscopically, while later a small incision is made to complete the transection of the liver parenchyma ${ }^{[6,7]}$. The liver is classified in individual territories according to the segmentation of the vessels and bile ducts, introduced by Couinaud in the $1950 \mathrm{~s}^{[8,9]}$, and the Brisbane 2000 nomenclature is utilized to define minor and major hepatectomy in the field of liver surgery ${ }^{[10,11]}$. Minor hepatectomy is defined as the resection of two or fewer Couinaud segments, while major hepatectomy is the removal of three or more Couinaud segments ${ }^{[1]}$. The first series on laparoscopic liver resections consisted mostly of minor liver resections ${ }^{[3,4,12,13]}$. The first laparoscopic major hepatectomy (LMH) was performed in $1997^{[14]}$. The higher risk for uncontrolled hemorrhage and the requirement of advanced technical expertise, particularly related to major vessel dissection, have slowed the broader adoption of minimally-invasive approaches for major hepatectomy ${ }^{[15]}$.

The technological advances of our era have also led to the broader implementation of robotics in several fields of surgery, including liver surgery. The ability to obtain three-dimensional and magnified intraoperative vision, the significant decrease in hand tremor, as well as the benefit for the surgeon of operating under more relaxed and comfortable circumstances, have led to a considerable growth in robotic surgery, which can overcome the rigid instrumentation and the limited two-dimensional vision associated with laparoscopic surgery $y^{[16,17]}$. These characteristics, along with the advent of wristed instruments, can lead to improved dexterity and higher precision in surgical dissection; this is of particular benefit to liver resection, as hilar dissection, curved transection of the liver parenchyma and the resection of lesions in the posterosuperior segments can be more feasible with the use of a robot ${ }^{[18]}$. The first large series of robotic liver resection was reported in $2002^{[19]}$, and although most current experience is based on minor resections, several studies have reported robotic major hepatectomy $(\mathrm{RMH})$. This review aims to summarize the current state of evidence about the outcomes after LMH vs. RMH. We acknowledge that there is still a very important role for open hepatectomy in cases of multiple bilobar liver tumors or large tumors near critical vascular structures. However, we will focus on the differences between LMH and RMH, as a full review of open major hepatectomy is beyond the scope of this review.

\section{INTERNATIONAL CONSENSUS AND LEARNING CURVES}

Before engaging in a head-to-head comparison between $\mathrm{LMH}$ and $\mathrm{RMH}$, it is worth mentioning two points that may favor the former approach. First, LMH has been performed for many more years than its robotic counterpart; second, irrespective of the procedural, hospitalization, and total economic cost, the cost of purchasing a robot for a hospital is considerable and has been a major limiting factor to the broader adoption of robotic liver surgery. These two points are of paramount importance, as data suggest that outcomes improve as experience with a surgical approach grows ${ }^{[20]}$. It is also worth mentioning that during the second international consensus on laparoscopic liver surgery (Morioka 2014), the jury concluded that laparoscopic minor hepatectomy had at that point already become standard practice, while LMH was still considered to be an innovative procedure still under exploration ${ }^{[11]}$. According to the 2018 international consensus statement on robotic hepatectomy, RMH was deemed to be as safe and feasible as both LMH and open major hepatectomy ${ }^{[21]}$.

For the purpose of this review, we performed a non-systematic search of the PubMed bibliographic database using combinations of the following terms: "laparoscopic", "robotic", "minimally invasive", "hepatectomy", "major hepatectomy", "liver resection", and "major liver resection" (last search March 2020). We included comparative or non-comparative studies reporting on the number of LMH and RMH cases. Tables 1, 2, and 3 present the previously published cases of $\mathrm{RMH}$ and $\mathrm{LMH}^{[6,7,12-14,20,22-109]}$, and it is apparent that the experience with $\mathrm{LMH}$ is greater than that of the robotic approach. 
Table 1. Previously published reports on robotic major hepatectomy

\begin{tabular}{|c|c|c|c|c|c|c|}
\hline \multirow[b]{2}{*}{ Author } & \multirow[b]{2}{*}{ Country/region } & \multirow[b]{2}{*}{ Study period } & \multirow[b]{2}{*}{$\begin{array}{l}\text { Total number of } \\
\text { robotic cases }\end{array}$} & \multicolumn{3}{|c|}{ Robotic major hepatectomy } \\
\hline & & & & Total major & $\begin{array}{c}\text { Left } \\
\text { hepatectomy }\end{array}$ & $\begin{array}{c}\text { Right } \\
\text { hepatectomy }\end{array}$ \\
\hline Giulianotti et al. ${ }^{[72]} 2011$ & Italy \& USA & Mar 2002-Mar 2009 & 70 & 27 & 5 & 20 \\
\hline Ji et al. ${ }^{[83]} 2011$ & China & Apr 2009-Jul 2009 & 13 & 9 & 6 & 2 \\
\hline Tsung et al. ${ }^{[20]} 2014$ & USA & Nov 2007-Dec 2011 & 57 & 21 & $\mathrm{n} / \mathrm{a}$ & $\mathrm{n} / \mathrm{a}$ \\
\hline Spampinato et al. ${ }^{[94]} 2014$ & Italy & Jan 2009-Dec 2012 & 25 & 25 & 7 & 16 \\
\hline Yu et al. ${ }^{[105]} 2014$ & South Korea & May 2010-Oct 2011 & 13 & 3 & 3 & 0 \\
\hline Wu et al. ${ }^{[22]} 2014$ & Taiwan & Jan 2012-Dec 2012 & 52 & 14 & 0 & 0 \\
\hline Felli et al. ${ }^{[23]} 2015$ & Italy & Apr 2013-May 2014 & 20 & 2 & 2 & 0 \\
\hline Lee et al. ${ }^{[24]} 2016$ & China & Sep 2010-Jan 2015 & 70 & 14 & 10 & 4 \\
\hline Kingham et al. ${ }^{[25]} 2016$ & USA & $2010-2014$ & 64 & 6 & 4 & 2 \\
\hline Lai et al. ${ }^{[26]} 2016$ & China & May 2009-Feb 2015 & 100 & 27 & 6 & 20 \\
\hline Lee et al. ${ }^{[27]} 2016$ & China & Sep 2010-Apr 2015 & 15 & 5 & 3 & 2 \\
\hline Sham et al. ${ }^{[28]} 2016$ & USA & May 2011-Dec 2014 & 71 & 17 & $\mathrm{n} / \mathrm{a}$ & $\mathrm{n} / \mathrm{a}$ \\
\hline Chen et al. ${ }^{[29]} 2016$ & Taiwan & May 2013-Aug 2015 & 13 & 13 & 0 & 13 \\
\hline Chen et al. ${ }^{[30,31]} 2017$ & Taiwan & Jan 2012-Oct 2015 & 183 & 92 & 32 & 41 \\
\hline Quijano et al..$^{[32]} 2017$ & Spain & Oct 2010-Apr 2016 & 21 & 5 & 2 & 1 \\
\hline Magistri et al. ${ }^{[33]} 2017$ & Italy & Jan 2012-May 2016 & 22 & 2 & 0 & 2 \\
\hline Efanov et al. ${ }^{[34]} 2017$ & Russia & May 2010-Jun 2016 & 40 & 2 & 2 & 0 \\
\hline Daskalaki et al. ${ }^{[35]} 2017$ & USA & Jan 2009-Dec 2013 & 68 & 29 & 2 & 21 \\
\hline Choi et al. ${ }^{[36]} 2017$ & South Korea & Dec 2008-May 2016 & 70 & 54 & 27 & 12 \\
\hline Khan et al. ${ }^{[37]} 2018$ & International & $2006-2016$ & 61 & 16 & 8 & 8 \\
\hline Goja et al. ${ }^{[38]} 2019$ & India & Feb 2015-Jan 2016 & 21 & 6 & 3 & 3 \\
\hline Lim et al. ${ }^{[39]} 2019^{\star}$ & France & $2011-2017$ & $61(55)$ & $9(4)$ & $\mathrm{n} / \mathrm{a}$ & $\mathrm{n} / \mathrm{a}$ \\
\hline Marino et al. ${ }^{[40]} 2019$ & Italy & Apr 2016-Mar 2017 & 14 & 14 & 0 & 14 \\
\hline Marino et al. ${ }^{[41]} 2019$ & Italy & Apr 2015-May 2017 & 35 & 35 & 35 & 0 \\
\hline Fruscione et al. ${ }^{[42]} 2019$ & USA & $2011-2016$ & 57 & 57 & 20 & 20 \\
\hline Gravetz et al. ${ }^{[43]} 2019$ & USA & 2013-2017 & 33 & 8 & $\mathrm{n} / \mathrm{a}$ & $\mathrm{n} / \mathrm{a}$ \\
\hline Magistri et al. ${ }^{[44]} 2019$ & Italy & Jul 2014-Sep 2017 & 60 & 3 & 1 & 2 \\
\hline Lee et al..$^{[45]} 2019$ & South Korea & Jun 2016-Apr 2018 & 13 & 8 & 8 & 0 \\
\hline Mejia et al. ${ }^{[46]} 2020$ & USA & Aug 2013-Sep 2018 & 43 & 8 & 4 & 4 \\
\hline Sucandy et al. ${ }^{[47]} 2020$ & USA & $2013-2018$ & 80 & 24 & 14 & 6 \\
\hline Beard et al. ${ }^{[48]} 2020^{*}$ & International & Jan 2008-Oct 2016 & 115 & 17 & 6 & 9 \\
\hline
\end{tabular}

${ }^{\star}$ Numbers in parentheses represent the number of cases after propensity score-matching. n/a: not available

Table 2. Previously published reports on laparoscopic major hepatectomy

\begin{tabular}{|c|c|c|c|c|c|c|}
\hline \multirow[b]{2}{*}{ Author } & \multirow[b]{2}{*}{ Country/region } & \multirow[b]{2}{*}{ Study period } & \multirow{2}{*}{$\begin{array}{c}\text { Total number } \\
\text { of laparoscopic } \\
\text { cases }\end{array}$} & \multicolumn{3}{|c|}{ Laparoscopic major hepatectomy } \\
\hline & & & & Total major & $\begin{array}{c}\text { Left } \\
\text { hepatectomy }\end{array}$ & $\begin{array}{c}\text { Right } \\
\text { hepatectomy }\end{array}$ \\
\hline Huscher et al. ${ }^{[14]} 1997$ & Italy & 1993-Dec 1995 & 20 & 14 & 6 & 5 \\
\hline Gigot et al. ${ }^{[49]} 2002$ & Europe & Feb 1994-Dec 2000 & 37 & 2 & $\mathrm{n} / \mathrm{a}$ & $\mathrm{n} / \mathrm{a}$ \\
\hline O'Rourke et al. ${ }^{[6]} 2004$ & Australia & Nov 1999-Sep 2002 & 12 & 12 & 0 & 12 \\
\hline Dulucq et al. ${ }^{[50]} 2005$ & France & Jan 1995-Jan 2004 & 32 & 11 & 4 & 6 \\
\hline Vibert et al. ${ }^{[51]} 2006$ & France & Jan 1995-Dec 2004 & 89 & 38 & 3 & 27 \\
\hline Topal et al. ${ }^{[52]} 2007$ & Belgium & $\mathrm{n} / \mathrm{a}$ & 2 & 2 & 0 & 2 \\
\hline Gayet et al. ${ }^{[53]} 2007$ & France & $\mathrm{n} / \mathrm{a}$ & 41 & 41 & 0 & 37 \\
\hline Koffron et al. ${ }^{[12]} 2007$ & USA & Jul 2001-Nov 2006 & 300 & 119 & 47 & 64 \\
\hline Dagher et al. ${ }^{[54]} 2007$ & France & Feb 1999-Jan 2006 & 70 & 19 & 5 & 12 \\
\hline Gumbs et al. ${ }^{[55]} 2008$ & France & $\mathrm{n} / \mathrm{a}$ & 3 & 3 & 0 & 0 \\
\hline Gumbs et al. ${ }^{[56]} 2008$ & France & $\mathrm{n} / \mathrm{a}$ & 5 & 5 & 0 & 0 \\
\hline Cho et al. ${ }^{[57]} 2008$ & South Korea & Jan 2004-Dec 2007 & 128 & 47 & 23 & 13 \\
\hline Buell et al. ${ }^{[13]} 2008$ & USA & Jan 2001-Apr 2008 & 253 & 69 & 24 & 33 \\
\hline Topal et al. ${ }^{[58]} 2008$ & Belgium & Oct 2002-Jun 2007 & 109 & 21 & 4 & 14 \\
\hline Dagher et al. ${ }^{[59]} 2008$ & France & Since Feb 1999 & 20 & 20 & 0 & 20 \\
\hline Wakabayashi et al. ${ }^{[60]} 2009$ & Japan & Jul 1995-Apr 2008 & 176 & 39 & 10 & 12 \\
\hline Castaing et al. ${ }^{[61]} 2009$ & France & Jan 1997-May 2007 & 60 & 26 & 0 & 22 \\
\hline
\end{tabular}


Nguyen et al. ${ }^{[62]} 2009$

Vigano et al. ${ }^{[63]} 2009$

Bryant et al. ${ }^{[64]} 2009$

Yoon et al. ${ }^{[65]} 2009$

Cho et al. ${ }^{[66]} 2009$

Baker et al. ${ }^{[67]} 2009$

Dagher et al. ${ }^{[68]} 2009$

Cai et al. ${ }^{[69]} 2009$

Yoon et al. ${ }^{[71]} 2010$

Nitta et al. ${ }^{[7]} 2010$

Dagher et al. ${ }^{[73]} 2010$

Martin et al. ${ }^{[74]} 2010$

Ji et al. ${ }^{[83]} 2011$

Shafaee et al. ${ }^{[75]} 2011$

Cho et al. ${ }^{[76]} 2011$

Bhojani et al. ${ }^{[78]} 2012$

Topal et al. ${ }^{[79]} 2012$

Cannon et al. ${ }^{[80]} 2012$

Gumbs et al. ${ }^{[81]} 2012$

Abu Hilal et al. ${ }^{[82]} 2013$

Tsung et al. ${ }^{[20]} 2014^{*}$

Spampinato et al. ${ }^{[94]} 2014$

Yu et al. ${ }^{[105]} 2014$

Wu et al. ${ }^{[22]} 2014$

Zhang et al. ${ }^{[85]} 2014$

Ahn et al. ${ }^{[86]} 2014$

Benkabbou et al. ${ }^{[87]} 2015$

Xiao et al. ${ }^{[88]} 2015$

Allard et al. ${ }^{[90]} 2015$

Beppu et al. ${ }^{[91]} 2015^{\star}$

de'Angelis et al. ${ }^{[92]} 2015$

van der Poel et al. ${ }^{[93]} 2016$

Lee et al. ${ }^{[24]} 2016$

Lai et al. ${ }^{[26]} 2016$

Takahara et al. ${ }^{[95]} 2016$

Cipriani et al. ${ }^{[96]} 2016$

Ratti et al. ${ }^{[97]} 2016$

Tranchart et al. ${ }^{[98]} 2016$

Untereiner et al. ${ }^{[99]} 2016$

Komatsu et al. ${ }^{[100]} 2016$

Martinez-Cecilia et al. ${ }^{[101]} 2017^{\star}$

Sotiropoulos et al. ${ }^{[102]} 2017$

Peng et al. ${ }^{[103]} 2017$

Chen et al. ${ }^{[104]} 2017$

Efanov et al. ${ }^{[34]} 2017$

Lim et al. ${ }^{[39]} 2019^{\star}$

Marino et al. ${ }^{[40]} 2019$

Fruscione et al. ${ }^{[42]} 2019$

Jang et al. ${ }^{[106]} 2019$

Cipriani et al. ${ }^{[107]} 2019$

Chen et al. ${ }^{[108]} 2019$

Lee et al. ${ }^{[45]} 2019$

Mejia et al. ${ }^{[46]} 2020$

Cipriani et al. ${ }^{[109]} 2020$

Beard et al. ${ }^{[48]} 2020$ *
Dagher et al. ${ }^{[70]} 2009$

Abu Hilal et al. ${ }^{[77]} 2011$

Medbery et al. ${ }^{[84]} 2014$

Takahara et al. ${ }^{[89]} 2015^{\star}$

\begin{tabular}{|c|c|c|c|c|c|}
\hline USA \& Europe & Feb 2000-Sep 2008 & 109 & 49 & 10 & 31 \\
\hline France & Jan 1996-Aug 2008 & 174 & 35 & $\mathrm{n} / \mathrm{a}$ & 23 \\
\hline France & May 1996-Dec 2007 & 166 & 31 & 11 & 19 \\
\hline South Korea & Oct 1998-Jun 2007 & 46 & 21 & 21 & 0 \\
\hline South Korea & May 2003-Apr 2007 & 40 & 12 & 0 & 5 \\
\hline USA & Jan 2006-May 2008 & 33 & 33 & 0 & 33 \\
\hline International & $1997-2008$ & 210 & 210 & 74 & 136 \\
\hline China & $2005-2007$ & 19 & 19 & 19 & 0 \\
\hline France & Feb 2002-Aug 2007 & 22 & 22 & 0 & 22 \\
\hline South Korea & Sep 2003-Nov 2008 & 69 & 21 & 2 & 6 \\
\hline Japan & Nov 2002-Dec 2008 & 42 & 42 & 16 & 14 \\
\hline Europe & $1998-2008$ & 163 & 16 & 4 & 10 \\
\hline USA & Jan 2000-Jun 2009 & 90 & 90 & 50 & 40 \\
\hline China & Apr 2009-Jul 2009 & 20 & 4 & 3 & 1 \\
\hline USA \& Europe & 1997-2009 & 68 & 22 & 1 & 12 \\
\hline Japan & Aug 2005-Feb 2010 & 27 & 20 & 5 & 10 \\
\hline UK & $2006-2009$ & 36 & 36 & 0 & 36 \\
\hline Canada & Jun 2006-May 2010 & 57 & 19 & 5 & 8 \\
\hline Belgium & Oct 2002-Dec 2008 & 20 & 20 & 4 & 13 \\
\hline USA & $2004-2010$ & 35 & 19 & 4 & 14 \\
\hline USA & Nov 2008-Oct 2010 & 53 & 25 & 8 & 13 \\
\hline UK & Mar 2006-Nov 2011 & 84 & 38 & 0 & 38 \\
\hline USA & Nov 2007-Dec 2011 & 114 & 42 & $\mathrm{n} / \mathrm{a}$ & $\mathrm{n} / \mathrm{a}$ \\
\hline Italy & Jan 2009-Dec 2012 & 25 & 25 & 8 & 15 \\
\hline South Korea & Jul 2007-Oct 2011 & 17 & 11 & 11 & 0 \\
\hline Taiwan & Jan 2012-Dec 2012 & 69 & 4 & 0 & 0 \\
\hline USA & May 2008-Mar 2012 & 48 & 48 & 0 & 48 \\
\hline China & July 2011-Mar 2013 & 25 & 25 & 0 & 25 \\
\hline South Korea & Jan 2005-Feb 2013 & 51 & 2 & 2 & 0 \\
\hline Morocco & Jun 2010-Feb 2013 & 13 & 2 & 1 & 1 \\
\hline China & Jan 2010-Dec 2012 & 41 & 4 & 0 & 0 \\
\hline Japan & $2000-2010$ & $436(387)$ & $46(42)$ & $\mathrm{n} / \mathrm{a}$ & $\mathrm{n} / \mathrm{a}$ \\
\hline France & Jan 2006-Dec 2013 & 176 & 80 & 14 & 63 \\
\hline Japan & Jan 2005-Dec 2010 & $210(171)$ & $12(10)$ & $\mathrm{n} / \mathrm{a}$ & $\mathrm{n} / \mathrm{a}$ \\
\hline France & Jan 2000-Dec 2013 & 52 & 18 & 2 & 15 \\
\hline UK & Aug 2003-Mar 2015 & 159 & 159 & 54 & 105 \\
\hline China & Nov 2003-Jan 2015 & 66 & 2 & 2 & 0 \\
\hline China & Oct 1998-Feb 2015 & 35 & 1 & 0 & 1 \\
\hline Japan & Jan 2011-Dec 2013 & 929 & 929 & 238 & 234 \\
\hline UK & Aug 2004-Apr 2015 & 133 & 65 & 8 & 43 \\
\hline Italy & $2008-2014$ & 25 & 6 & 4 & 2 \\
\hline International & $1997-2013$ & 89 & 7 & 3 & 4 \\
\hline France & Jan 2012-Jan 2015 & 18 & 2 & 2 & 0 \\
\hline France & Jan 2006-May 2014 & 38 & 38 & 10 & 28 \\
\hline Europe & Jan 2005-Dec 2012 & $287(225)$ & $49(47)$ & $\mathrm{n} / \mathrm{a}$ & $\mathrm{n} / \mathrm{a}$ \\
\hline Greece & Jan 2012-Jan 2017 & 42 & 1 & 1 & 0 \\
\hline China & Jan 2013-Oct 2016 & 36 & 15 & 15 & 0 \\
\hline China & Apr 2015-Sep 2016 & 225 & 126 & 26 & 43 \\
\hline Russia & May 2010-Jun 2016 & 91 & 11 & 2 & 9 \\
\hline France & $2011-2017$ & $111(55)$ & $15(8)$ & $\mathrm{n} / \mathrm{a}$ & $\mathrm{n} / \mathrm{a}$ \\
\hline Italy & Apr 2016-Mar 2017 & 20 & 20 & 0 & 20 \\
\hline USA & $2011-2016$ & 116 & 116 & 22 & 46 \\
\hline South Korea & Jan 2014-Jul 2017 & 37 & 17 & 9 & 8 \\
\hline Italy & Jan 2005-Nov 2017 & 145 & 145 & 59 & 86 \\
\hline Taiwan & Dec 2010-Dec 2016 & 436 & 90 & 31 & 52 \\
\hline South Korea & Jun 2016-Apr 2018 & 10 & 3 & 3 & 0 \\
\hline USA & Jun 2005-Sep 2018 & 171 & 46 & 13 & 33 \\
\hline Europe & Jan 2007-Feb 2016 & $597(545)$ & $597(545)$ & $215(172)$ & $382(351)$ \\
\hline International & Jul 2002-Oct 2017 & $514(115)$ & $53(21)$ & $17(n / a)$ & $33(n / a)$ \\
\hline
\end{tabular}

${ }^{\star}$ Numbers in parentheses represent the number of cases after propensity score-matching. $n / a$ : not available 
Table 3. Previously published reports on the comparison of laparoscopic and robotic liver resection along with the number of major hepatectomy cases in each group

\begin{tabular}{|c|c|c|c|c|}
\hline Author & Total laparoscopic & Laparoscopic major hepatectomy & Total robotic & Robotic major hepatectomy \\
\hline Ji et al. ${ }^{[83]} 2011$ & 20 & 4 & 13 & 9 \\
\hline Tsung et al. ${ }^{[20]} 2014$ & 114 & 42 & 57 & 21 \\
\hline Spampinato et al. ${ }^{[94]} 2014$ & 25 & 25 & 25 & 25 \\
\hline Yu et al. ${ }^{[105]} 2014$ & 17 & 11 & 13 & 3 \\
\hline Wu et al. ${ }^{[22]} 2014$ & 69 & 4 & 52 & 14 \\
\hline Lee et al. ${ }^{[24]} 2016$ & 66 & 2 & 70 & 14 \\
\hline Lai et al. ${ }^{[26]} 2016$ & 35 & 1 & 100 & 27 \\
\hline Efanov et al. ${ }^{[34]} 2017$ & 91 & 11 & 40 & 2 \\
\hline Lim et al. ${ }^{[39]} 2019^{\star}$ & $111(55)$ & $15(8)$ & $61(55)$ & $9(4)$ \\
\hline Marino et al. ${ }^{[40]} 2019$ & 20 & 20 & 14 & 14 \\
\hline Fruscione et al. ${ }^{[42]} 2019$ & 116 & 116 & 57 & 57 \\
\hline Lee et al. ${ }^{[45]} 2019$ & 10 & 3 & 13 & 8 \\
\hline Mejia et al. ${ }^{[46]} 2020$ & 171 & 46 & 43 & 8 \\
\hline Beard et al. ${ }^{[48]} 2020^{*}$ & $514(115)$ & $53(21)$ & 115 & 18 \\
\hline
\end{tabular}

${ }^{\star}$ Numbers in parentheses represent the number of cases after propensity score-matching

Determining the learning curve for each approach is also of major significance. The learning curve is "the improvement in performance over time or the change in the ability to complete a task until failure is decreased to a constant acceptable rate"[110]. Data suggest that the learning curve for LMH is around 45-60 cases $^{[93,111-113]}$. van der Poel et al ${ }^{[93]}$ reported that 55 is the "golden" number for LMH; however, all surgical operations were performed by two experienced hepatobiliary surgeons with at least three years of additional experience on minor laparoscopic hepatectomy. For RMH, Chen et al. ${ }^{[30]}$ described an initial phase of 15 patients followed by an intermediate phase of 25 patients. The accumulated experience of the first 15 cases (defined as the "initial learning curve"), mostly comprised of right and left hemihepatectomies, was followed by more complex cases, such as trisectionectomy and 8-5-4 trisegmentectomy, in the next 25 cases ("phase of increased competency"). Their last 52-case "matured phase" was associated with an overall improvement in outcomes. However, the authors did not mention who their "learning curve" refers to, as "all procedures were performed by the same operative team", but they do not specify their prior experience with minor robotic resections or even with $\mathrm{LMH}$. Tsung et al ${ }^{[20]}$ reported that the outcomes of their robotic cases between 2010-2011 were superior to those of the robotic cases between 2007-2010, but the authors pooled together both minor and major resections for this comparison.

\section{OPERATING TIME}

A systematic review and pooled analysis of outcomes on robotic liver resections showed that the mean operating time for $\mathrm{RMH}$ ( $\geq 4$ segments) was $405 \pm 100 \mathrm{~min}^{[18]}$, while another more recent systematic review reported similar pooled mean operating rime for RMH ( $\geq 3$ segments) of $403.4 \pm 107.5 \mathrm{~min}^{[114]}$. A systematic literature review on $\mathrm{LMH}^{[115]}$ showed that mean operating time in all individuals studies was lower than the pooled operating times reported in the RMH systematic reviews ${ }^{[18,114]}$. Additionally, in a systematic review comparing LMH to open major hepatectomy, the pooled mean operating time in the LMH arm was $285 \pm 105.6 \mathrm{~min}^{[116]}$. Similarly, in a large multicenter study from Europe, Cipriani et al ${ }^{[109]}$ reported a median operating time of $300 \mathrm{~min}$ (IQR 205-380) for LMH, and more specifically $300 \mathrm{~min}$ (IQR 240-402) for right hepatectomy and $270 \mathrm{~min}$ (IQR 160-290) for left hepatectomy. Tsung et al. ${ }^{[20]}$ compared RMH vs. LMH, and showed that both overall operating room time (452 $\mathrm{min} v s .348 .5 \mathrm{~min}$ ) and operating time (330 $\mathrm{min}$ vs. $280.5 \mathrm{~min}$ ) were significantly longer in the RMH group. Spampinato et al ${ }^{[94]}$ also showed that operating time was longer in RMH (430, IQR 240-725 min) when compared to LMH (360, IQR 180-600 min), while all procedures were performed by surgeons experienced in minimally-invasive liver surgery. Notably, a more recent study showed no difference in median operating time between RMH (194, range 152-255 min) and LMH (204, 149-280 min), and all of the operations were again performed by experienced minimally-invasive 
hepatobiliary surgeons ${ }^{[42]}$. A Korean group recently published the initial experience of a single surgeon with robotic liver surgery and showed that there was no difference in operating time between robotic and laparoscopic left hepatectomy $(248.6 \pm 37.5 \mathrm{~min} v s .226 .7 \pm 26.6 \mathrm{~min})^{[45]}$. Another recent study comparing robotic $v s$. laparoscopic right hepatectomy demonstrated that operating time was significantly shorter in the robotic group compared to the laparoscopic one ( $425 \pm 139 \mathrm{~min} v s .565 .18 \pm 183.73 \mathrm{~min})$, and all procedures were performed by the same young surgeon ${ }^{[40]}$. That may serve as an indicator that as experience with $\mathrm{RMH}$ grows, operating time seems to decrease and to be equivalent to, or even shorter than, that of LMH. However, a major confounding factor is surgeon's surgical expertise and prior experience with minimallyinvasive major hepatectomy; thus, future studies comparing operating time, as well as other parameters, between RMH and LMH should always mention primary surgeon's prior experience and should make sure that the two comparison groups are equivalent regarding this parameter.

\section{ESTIMATED BLOOD LOSS}

The pooled estimated blood loss (EBL) in RMH based on two systematic reviews was $543.4 \pm 371 \mathrm{~mL}^{[114]}$ and $380 \pm 505 \mathrm{~mL}^{[18]}$, respectively. The pooled mean EBL for the LMH arm in a systematic review comparing LMH to open major hepatectomy was $450.6 \pm 563.2^{[116]}$, which is comparable to the pooled rates reported in the RMH systematic reviews ${ }^{[18,114]}$. However, major deviations were found between the individual RMH or LMH studies themselves included in each systematic review. Cipriani et al.$^{[109]}$ reported a median EBL of $350 \mathrm{~mL}$ (IQR 125-1350) for LMH, and more specifically $400 \mathrm{~mL}$ (IQR 200-800) for right hepatectomy and $300 \mathrm{~mL}$ (IQR 50-260) for left hepatectomy. Studies directly comparing EBL between RMH and LMH showed that EBL in RMH was lower than that in LMH, while the difference was not statistically significant in any of the individual studies ${ }^{[20,40,42,94]}$.

\section{LENGTH OF STAY}

Two prior systematic reviews on RMH reported a pooled mean hospital length of stay (LOS) of $10.5 \pm 4.8^{[114]}$ and $11 \pm 6$ days $^{[18]}$, respectively. The mean LOS of most individual studies included in a systematic review on $\mathrm{LMH}^{[115]}$ was shorter than that of the two RMH systematic reviews. Another systematic review showed that the pooled mean LOS for LMH was $10 \pm 8.7$ days ${ }^{[116]}$. Cipriani et al.$^{[109]}$ reported a median LOS of 6 days (IQR 4-10) for LMH, and more specifically 7 days (IQR 4-13) for right hepatectomy, and 5 days (IQR 4-10) for left hepatectomy. Studies reporting on the direct comparison of RMH $v$ s. LMH did not demonstrate any statistically significant difference between the two $\operatorname{arms}^{[20,40,42,94]}$.

\section{COMPLICATIONS, SURVIVAL AND ONCOLOGIC OUTCOMES}

When comparing RMH and LMH, Tsung et al ${ }^{[20]}$ reported that no difference was observed between the two groups with a complication rate of $24 \%(n=5 / 21) v s .32 \%(n=13 / 42)$, respectively, while only one patient in the RMH group experienced a major complication (Clavien-Dindo grade $\geq 3)(4.8 \% v \mathcal{~ s . ~} 0 \%$, respectively). The 90 -day mortality rate was $0 \%$ in both groups ${ }^{[20]}$. Similar complication rates were documented by Spampinato et al. ${ }^{[94]}$ RMH: $20 \%(n=5 / 25)$ vs. LMH: $36 \%(n=9 / 25)$, with $4 \%(n=1 / 25)$ and $12 \%(n=3 / 25)$ of the patients experiencing a major complication (Clavien-Dindo grade $\geq 3$ ), respectively. However, one patient in the LMH group died ${ }^{[94]}$. Marino et al. ${ }^{[40]}$ also failed to show a difference in morbidity with $21.4 \%(n=3 / 14)$ of the patients in the RMH arm $v s .15 \%(n=3 / 20)$ in the LMH group experiencing any complications, while no major complications occurred. Ninety-day mortality was $0 \%$ in both groups ${ }^{[40]}$. The largest and most recent comparative study between $\mathrm{RMH}$ and $\mathrm{LMH}$ was performed by Fruscione et al ${ }^{[42]}$ and also did not show a significant difference in complications between the two groups. Specifically, the complication rate for RMH was $28.1 \%(n=16 / 57)$ and for LMH 35.3\% $(n=41 / 116)$, with $7 \%(n=4 / 57)$ and $9.5 \%(n=11 / 116)$ being classified as major complications (Clavien-Dindo grade $\geq 3$ ). No death was reported in either of the comparison arms ${ }^{[42]}$. Additionally, when RMH and LMH were performed for liver malignancies, none of the four studies showed a difference in surgical margin status between the two approaches (positive margins: 0\%-8.3\% vs. 7\%-15\%, respectively), and long-term outcomes were comparable when reported ${ }^{[20,40,42,94]}$. 


\section{ECONOMIC COST}

Mejia et al ${ }^{[46]}$ reported that the adjusted room and board charges were significantly lower in the LMH $v s$. the RMH group, with no other difference between the two groups regarding economic cost. Of note, when comparing the cost of LMH vs. RMH, the fixed capital cost $(\$ 1,000,000-\$ 2,600,000$ for a robotic system with a 10-year longevity period $)^{[117-120]}$ and annual maintenance cost $(\$ 90,000-\$ 175,000)^{[120]}$ for a hospital to purchase and maintain a surgical robot, should also be taken into consideration. The addition of this cost can be burdensome, particularly for low-volume liver surgery centers, and this remains a significant driving factor for the slow spread of RMH and robotic liver surgery in general. It should also be noted that access to the robot in the operating room can be a challenge due to competition with other surgical service lines.

\section{CONCLUSION}

The introduction of laparoscopy and robotic surgical systems in liver surgery has significantly changed the current state of practice. Although both approaches have been more widely tested for minor liver resections, the number of LMHs and RMHs performed worldwide has significantly increased over recent years, and is still on the rise. Although there is a considerable deviation in outcomes after RMH, especially during early experience, when RMH is performed by experienced surgeons in high-volume liver centers, it can be associated with equivalent operating time, EBL, LOS, morbidity and mortality, and comparable oncologic outcomes in terms of achieving a margin-negative resection and long-term overall survival. The fixed capital and annual maintenance costs for the robotic surgical system may pose a significant obstacle in the broader adoption of RMH, particularly in low-volume centers.

\section{DECLARATIONS}

\section{Authors' contributions}

Study concept, data acquisition, data analysis and interpretation, drafting, critical revision, final approval of the manuscript: Ziogas IA, Tohme S, Geller DA

\section{Availability of data and materials}

Not applicable.

\section{Financial support and sponsorship}

None.

\section{Conflicts of interest}

All authors declared that there are no conflicts of interest.

\section{Ethical approval and consent to participate}

Not applicable.

\section{Consent for publication}

Not applicable.

\section{Copyright}

(c) The Author(s) 2020.

\section{REFERENCES}

1. Nguyen KT, Gamblin TC, Geller DA. World review of laparoscopic liver resection-2,804 patients. Ann Surg 2009;250:831-41.

2. Ciria R, Cherqui D, Geller DA, Briceno J, Wakabayashi G. Comparative short-term benefits of laparoscopic liver resection: 9000 cases and climbing. Ann Surg 2016;263:761-77.

3. Reich H, McGlynn F, DeCaprio J, Budin R. Laparoscopic excision of benign liver lesions. Obstet Gynecol 1991;78:956-8. 
4. Gagner M, Rheault M, Dubuc J. Laparoscopic partial hepatectomy for liver tumor. Surg Endosc 1992;6:99.

5. Ziogas IA, Tsoulfas G. Advances and challenges in laparoscopic surgery in the management of hepatocellular carcinoma. World J Gastrointest Surg 2017;9:233-45.

6. O’Rourke N, Fielding G. Laparoscopic right hepatectomy: surgical technique. J Gastrointest Surg 2004;8:213-6.

7. Nitta H, Sasaki A, Fujita T, Itabashi H, Hoshikawa K, et al. Laparoscopy-assisted major liver resections employing a hanging technique: the original procedure. Ann Surg 2010;251:450-3.

8. Couinaud C. Lobes et segments hepatiques. Notes sur l'architecture anatomique et chirurgicale du foie. Press Med 1954;62:709-12. (in French)

9. Couinaud C. Le foie: études anatomiques et chirurgicales. Paris: Masson; 1957. (in French)

10. Strasberg S, Belghiti J, Clavien PA, Gadzijev E, Garden JO, et al. The Brisbane 2000 terminology of liver anatomy and resections. HPB 2000;2:333-9.

11. Wakabayashi G, Cherqui D, Geller DA, Buell JF, Kaneko H, et al. Recommendations for laparoscopic liver resection: a report from the second international consensus conference held in Morioka. Ann Surg 2015;261:619-29.

12. Koffron AJ, Auffenberg G, Kung R, Abecassis M. Evaluation of 300 minimally invasive liver resections at a single institution: Less is more. Ann Surg 2007;246:385-92.

13. Buell JF, Thomas MT, Rudich S, Marvin M, Nagubandi R, et al. Experience with more than 500 minimally invasive hepatic procedures. Ann Surg 2008;248:475-85.

14. Huscher CG, Lirici MM, Chiodini S, Recher A. Current position of advanced laparoscopic surgery of the liver. J R Coll Surg Edinb 1997;42:219-25.

15. Nguyen KT, Geller DA. Laparoscopic liver resection-current update. Surg Clin North Am 2010;90:749-60.

16. Marescaux J, Leroy J, Gagner M, Rubino F, Mutter D, et al. Transatlantic robot-assisted telesurgery. Nature 2001;413:379-80.

17. Hanna T, Imber C. Robotics in HPB surgery. Ann R Coll Surg Engl 2018;100:31-7.

18. Nota CL, Rinkes IHB, Molenaar IQ, van Santvoort HC, Fong Y, et al. Robot-assisted laparoscopic liver resection: a systematic review and pooled analysis of minor and major hepatectomies. HPB (Oxford) 2016;18:113-20.

19. Giulianotti PC, Coratti A, Angelini M, Sbrana F, Cecconi S, et al. Robotics in general surgery: personal experience in a large community hospital. Arch Surg 2003;138:777-84.

20. Tsung A, Geller DA, Sukato DC, Sabbaghian S, Tohme S, et al. Robotic versus laparoscopic hepatectomy: a matched comparison. Ann Surg 2014;259:549-55.

21. Liu R, Wakabayashi G, Kim HJ, Choi GH, Yiengpruksawan A, et al. International consensus statement on robotic hepatectomy surgery in 2018. World J Gastroenterol 2019;25:1432.

22. Wu YM, Hu RH, Lai HS, Lee PH. Robotic-assisted minimally invasive liver resection. Asian J Surg 2014;37:53-7.

23. Felli E, Santoro R, Colasanti M, Vennarecci G, Lepiane P, et al. Robotic liver surgery: preliminary experience in a tertiary hepatobiliary unit. Updates Surg 2015;67:27-32.

24. Lee KF, Cheung YS, Chong CC, Wong J, Fong AK, et al. Laparoscopic and robotic hepatectomy: experience from a single centre. ANZ J Surg 2016;86:122-6.

25. Kingham TP, Leung U, Kuk D, Gönen M, D’Angelica MI, et al. Robotic liver resection: a case-matched comparison. World J Surg 2016;40:1422-8.

26. Lai EC, Tang CN. Long-term survival analysis of robotic versus conventional laparoscopic hepatectomy for hepatocellular carcinoma: a comparative study. Surg Laparosc Endosc Percutan Tech 2016;26:162-6.

27. Lee KF, Fong AK, Chong CC, Cheung SY, Wong J, et al. Robotic liver resection for primary hepatolithiasis: is it beneficial? World J Surg 2016;40:2490-6.

28. Sham JG, Richards MK, Seo YD, Pillarisetty VG, Yeung RS, et al. Efficacy and cost of robotic hepatectomy: is the robot cost-prohibitive? J Robot Surg 2016;10:307-13.

29. Chen PD, Wu CY, Hu RH, Ho CM, Lee PH, et al. Robotic liver donor right hepatectomy: a pure, minimally invasive approach. Liver Transpl 2016;22:1509-18.

30. Chen PD, Wu CY, Hu RH, Chen CN, Yuan RH, et al. Robotic major hepatectomy: is there a learning curve? Surgery 2017;161:642-9.

31. Chen PD, Wu CY, Hu RH, Chou WH, Lai HS, et al. Robotic versus open hepatectomy for hepatocellular carcinoma: a matched comparison. Ann Surg Oncol 2017;24:1021-8.

32. Quijano Y, Vicente E, Ielpo B, Duran H, Diaz E, et al. Hepatobilio-pancreatic robotic surgery: Initial experience from a single center institute. J Robot Surg 2017;11:355-65.

33. Magistri P, Tarantino G, Guidetti C, Assirati G, Olivieri T, et al. Laparoscopic versus robotic surgery for hepatocellular carcinoma: the first 46 consecutive cases. J Surg Res 2017;217:92-9.

34. Efanov M, Alikhanov R, Tsvirkun V, Kazakov I, Melekhina O, et al. Comparative analysis of learning curve in complex robot-assisted and laparoscopic liver resection. HPB 2017;19:818-24.

35. Daskalaki D, Gonzalez-Heredia R, Brown M, Bianco FM, Tzvetanov I, et al. Financial impact of the robotic approach in liver surgery: a comparative study of clinical outcomes and costs between the robotic and open technique in a single institution. J Laparoendosc Adv Surg Tech 2017;27:375-82.

36. Choi GH, Chong JU, Han DH, Choi JS, Lee WJ. Robotic hepatectomy: the Korean experience and perspective. Hepatobiliary Surg Nutr 2017;6:230-8.

37. Khan S, Beard RE, Kingham PT, Fong Y, Boerner T, et al. Long-term oncologic outcomes following robotic liver resections for primary 
hepatobiliary malignancies: a multicenter study. Ann Surg Oncol 2018;25:2652-60.

38. Goja S, Yadav SK, Chaudhary RJ, Singh MK, Soin AS. Transition from open to robotic assisted liver resection: a retrospective comparative study. Is experience of laparoscopic liver resections needed? Laparosc Endosc Robot Surg 2019;2:94-8.

39. Lim C, Salloum C, Tudisco A, Ricci C, Osseis M, et al. Short- and long-term outcomes after robotic and laparoscopic liver resection for malignancies: a propensity score-matched study. World J Surg 2019;43:1594-603.

40. Marino MV, Shabat G, Guarrasi D, Gulotta G, Komorowski AL. Comparative study of the initial experience in performing robotic and laparoscopic right hepatectomy with technical description of the robotic technique. Dig Surg 2019;36:241-50.

41. Marino MV, Gulotta G, Komorowski AL. Fully robotic left hepatectomy for malignant tumor: technique and initial results. Updates Surg 2019;71:129-35.

42. Fruscione M, Pickens R, Baker EH, Cochran A, Khan A, et al. Robotic-assisted versus laparoscopic major liver resection: analysis of outcomes from a single center. HPB 2019;21:906-11.

43. Gravetz A, Sucandy I, Wilfong C, Patel N, Spence J, et al. Single-institution early experience and learning curve with robotic liver resections. Am Surg 2019;85:115-9.

44. Magistri P, Guerrini GP, Ballarin R, Assirati G, Tarantino G, et al. Improving outcomes defending patient safety: the learning journey in robotic liver resections. Biomed Res Int 2019;2019:1835085.

45. Lee SJ, Lee JH, Lee YJ, Kim SC, Hwang DW, et al. The feasibility of robotic left-side hepatectomy with comparison of laparoscopic and open approach: consecutive series of single surgeon. Int J Med Robot 2019;15:e1982.

46. Mejia A, Cheng SS, Vivian E, Shah J, Oduor H, et al. Minimally invasive liver resection in the era of robotics: analysis of 214 cases. Surg Endosc 2020;34:339-48.

47. Sucandy I, Schlosser S, Bourdeau T, Spence J, Attili A, et al. Robotic hepatectomy for benign and malignant liver tumors. J Robot Surg 2020;14:75-80.

48. Beard RE, Khan S, Troisi RI, Montalti R, Vanlander A, et al. Long-term and oncologic outcomes of robotic versus laparoscopic liver resection for metastatic colorectal cancer: a multicenter, propensity score matching analysis. World J Surg 2020;44:887-95.

49. Gigot JF, Glineur D, Santiago Azagra J, Goergen M, Ceuterick M, et al; Hepatobiliary and Pancreatic Section of the Royal Belgian Society of Surgery and the Belgian Group for Endoscopic Surgery. Laparoscopic liver resection for malignant liver tumors: preliminary results of a multicenter European study. Ann Surg 2002;236:90-7.

50. Dulucq JL, Wintringer P, Stabilini C, Berticelli J, Mahajna A. Laparoscopic liver resections: a single center experience. Surg Endosc 2005;19:886-91.

51. Vibert E, Perniceni T, Levard H, Denet C, Shahri NK, et al. Laparoscopic liver resection. Br J Surg 2006;93:67-72.

52. Topal B, Aerts R, Penninckx F. Laparoscopic intrahepatic Glissonian approach for right hepatectomy is safe, simple, and reproducible. Surg Endosc 2007;21:2111.

53. Gayet B, Cavaliere D, Vibert E, Perniceni T, Levard H, et al. Totally laparoscopic right hepatectomy. Am J Surg 2007;194:685-9.

54. Dagher I, Proske JM, Carloni A, Richa H, Tranchart H, et al. Laparoscopic liver resection: results for 70 patients. Surg Endosc 2007;21:619-24.

55. Gumbs AA, Bar-Zakai B, Gayet B. Totally laparoscopic extended left hepatectomy. J Gastrointest Surg 2008;12:1152.

56. Gumbs AA, Gayet B. Multimedia article. Totally laparoscopic extended right hepatectomy. Surg Endosc 2008;22:2076-7.

57. Cho JY, Han HS, Yoon YS, Shin SH. Experiences of laparoscopic liver resection including lesions in the posterosuperior segments of the liver. Surg Endosc 2008;22:2344-9.

58. Topal B, Fieuws S, Aerts R, Vandeweyer H, Penninckx F. Laparoscopic versus open liver resection of hepatic neoplasms: comparative analysis of short-term results. Surg Endosc 2008;22:2208-13.

59. Dagher I, Caillard C, Proske JM, Carloni A, Lainas P, et al. Laparoscopic right hepatectomy: original technique and results. J Am Coll Surg 2008;206:756-60.

60. Wakabayashi G, Nitta H, Takahara T, Shimazu M, Kitajima M, et al. Standardization of basic skills for laparoscopic liver surgery towards laparoscopic donor hepatectomy. J Hepatobiliary Pancreat Surg 2009;16:439-44.

61. Castaing D, Vibert E, Ricca L, Azoulay D, Adam R, et al. Oncologic results of laparoscopic versus open hepatectomy for colorectal liver metastases in two specialized centers. Ann Surg 2009;250:849-55.

62. Nguyen KT, Laurent A, Dagher I, Geller DA, Steel J, et al. Minimally invasive liver resection for metastatic colorectal cancer: a multiinstitutional, international report of safety, feasibility, and early outcomes. Ann Surg 2009;250:842-8.

63. Vigano L, Laurent A, Tayar C, Tomatis M, Ponti A, et al. The learning curve in laparoscopic liver resection: improved feasibility and reproducibility. Ann Surg 2009;250:772-80.

64. Bryant R, Laurent A, Tayar C, Cherqui D. Laparoscopic liver resection-understanding its role in current practice: the Henri Mondor Hospital experience. Ann Surg 2009;250:103-11.

65. Yoon YS, Han HS, Shin SH, Cho JY, Min SK, et al. Laparoscopic treatment for intrahepatic duct stones in the era of laparoscopy: laparoscopic intrahepatic duct exploration and laparoscopic hepatectomy. Ann Surg 2009;249:286-91.

66. Cho JY, Han HS, Yoon YS, Shin SH. Outcomes of laparoscopic liver resection for lesions located in the right side of the liver. Arch Surg 2009;144:25-9.

67. Baker TB, Jay CL, Ladner DP, Preczewski LB, Clark L, et al. Laparoscopy-assisted and open living donor right hepatectomy: a comparative study of outcomes. Surgery 2009;146:817-23; discussion 823-5.

68. Dagher I, O’Rourke N, Geller DA, Cherqui D, Belli G, et al. Laparoscopic major hepatectomy: an evolution in standard of care. Ann Surg 2009;250:856-60. 
69. Cai XJ, Wang YF, Liang YL, Yu H, Liang X. Laparoscopic left hemihepatectomy: a safety and feasibility study of 19 cases. Surg Endosc 2009;23:2556-62.

70. Dagher I, Di Giuro G, Dubrez J, Lainas P, Smadja C, et al. Laparoscopic versus open right hepatectomy: a comparative study. Am J Surg 2009;198:173-7.

71. Yoon YS, Han HS, Cho JY, Ahn KS. Total laparoscopic liver resection for hepatocellular carcinoma located in all segments of the liver. Surg Endosc 2010;24:1630-7.

72. Giulianotti PC, Coratti A, Sbrana F, Addeo P, Bianco FM, et al. Robotic liver surgery: results for 70 resections. Surgery 2011;149:29-39.

73. Dagher I, Belli G, Fantini C, Laurent A, Tayar C, et al. Laparoscopic hepatectomy for hepatocellular carcinoma: a European experience. J Am Coll Surg 2010;211:16-23.

74. Martin RC, Scoggins CR, McMasters KM. Laparoscopic hepatic lobectomy: advantages of a minimally invasive approach. J Am Coll Surg 2010;210:627-34, 634-6.

75. Shafaee Z, Kazaryan AM, Marvin MR, Cannon R, Buell JF, et al. Is laparoscopic repeat hepatectomy feasible? A tri-institutional analysis. J Am Coll Surg 2011;212:171-9.

76. Cho A, Yamamoto H, Kainuma O, Souda H, Ikeda A, et al. Safe and feasible extrahepatic Glissonean access in laparoscopic anatomical liver resection. Surg Endosc 2011;25:1333-6.

77. Abu Hilal M, Di Fabio F, Teng MJ, Lykoudis P, Primrose JN, et al. Single-centre comparative study of laparoscopic versus open right hepatectomy. J Gastrointest Surg 2011;15:818-23.

78. Bhojani FD, Fox A, Pitzul K, Gallinger S, Wei A, et al. Clinical and economic comparison of laparoscopic to open liver resections using a 2-to-1 matched pair analysis: an institutional experience. J Am Coll Surg 2012;214:184-95.

79. Topal H, Tiek J, Aerts R, Topal B. Outcome of laparoscopic major liver resection for colorectal metastases. Surg Endosc 2012;26:2451-5.

80. Cannon RM, Scoggins CR, Callender GG, McMasters KM, Martin RC 2nd. Laparoscopic versus open resection of hepatic colorectal metastases. Surgery 2012;152:567-73; discussion 573-4.

81. Gumbs AA, Tsai T, Hoffman JP. Initial experience with laparoscopic hepatic resection at a comprehensive cancer center. Surg Endosc 2012;26:480-7.

82. Abu Hilal M, Di Fabio F, Syed S, Wiltshire R, Dimovska E, et al. Assessment of the financial implications for laparoscopic liver surgery: a single-centre UK cost analysis for minor and major hepatectomy. Surg Endosc 2013;27:2542-50.

83. Ji WB, Wang HG, Zhao ZM, Duan WD, Lu F, et al. Robotic-assisted laparoscopic anatomic hepatectomy in China: initial experience. Ann Surg 2011;253:342-8.

84. Medbery RL, Chadid TS, Sweeney JF, Knechtle SJ, Kooby DA, et al. Laparoscopic vs open right hepatectomy: a value-based analysis. J Am Coll Surg 2014;218:929-39.

85. Zhang X, Yang J, Yan L, Li B, Wen T, et al. Comparison of laparoscopy-assisted and open donor right hepatectomy: a prospective casematched study from china. J Gastrointest Surg 2014;18:744-50.

86. Ahn KS, Kang KJ, Kim YH, Kim TS, Lim TJ. A propensity score-matched case-control comparative study of laparoscopic and open liver resection for hepatocellular carcinoma. J Laparoendosc Adv Surg Tech A 2014;24:872-7.

87. Benkabbou A, Souadka A, Serji B, Hachim H, El Malki HO, et al. Laparoscopic liver resection: initial experience in a North-African single center. Tunis Med 2015;93:523-6.

88. Xiao L, Xiang LJ, Li JW, Chen J, Fan YD, et al. Laparoscopic versus open liver resection for hepatocellular carcinoma in posterosuperior segments. Surg Endosc 2015;29:2994-3001.

89. Takahara T, Wakabayashi G, Beppu T, Aihara A, Hasegawa K, et al. Long-term and perioperative outcomes of laparoscopic versus open liver resection for hepatocellular carcinoma with propensity score matching: a multi-institutional Japanese study. J Hepatobiliary Pancreat Sci 2015;22:721-7.

90. Allard MA, Cunha AS, Gayet B, Adam R, Goere D, et al. Early and long-term oncological outcomes after laparoscopic resection for colorectal liver metastases: a propensity score-based analysis. Ann Surg 2015;262:794-802.

91. Beppu T, Wakabayashi G, Hasegawa K, Gotohda N, Mizuguchi T, et al. Long-term and perioperative outcomes of laparoscopic versus open liver resection for colorectal liver metastases with propensity score matching: a multi-institutional Japanese study. J Hepatobiliary Pancreat Sci 2015;22:711-20.

92. de'Angelis N, Eshkenazy R, Brunetti F, Valente R, Costa M, et al. Laparoscopic versus open resection for colorectal liver metastases: a single-center study with propensity score analysis. J Laparoendosc Adv Surg Tech A 2015;25:12-20.

93. van der Poel MJ, Besselink MG, Cipriani F, Armstrong T, Takhar AS, et al. Outcome and learning curve in 159 consecutive patients undergoing total laparoscopic hemihepatectomy. JAMA Surg 2016;151:923-8.

94. Spampinato MG, Coratti A, Bianco L, Caniglia F, Laurenzi A, et al. Perioperative outcomes of laparoscopic and robot-assisted major hepatectomies: an Italian multi-institutional comparative study. Surg Endosc 2014;28:2973-9.

95. Takahara T, Wakabayashi G, Konno H, Gotoh M, Yamaue H, et al. Comparison of laparoscopic major hepatectomy with propensity score matched open cases from the national clinical database in Japan. J Hepatobiliary Pancreat Sci 2016;23:721-34.

96. Cipriani F, Rawashdeh M, Stanton L, Armstrong T, Takhar A, et al. Propensity score-based analysis of outcomes of laparoscopic versus open liver resection for colorectal metastases. Br J Surg 2016;103:1504-12.

97. Ratti F, Catena M, Di Palo S, Staudacher C, Aldrighetti L. Impact of totally laparoscopic combined management of colorectal cancer with synchronous hepatic metastases on severity of complications: a propensity-score-based analysis. Surg Endosc 2016;30:4934-45.

98. Tranchart H, Fuks D, Vigano L, Ferretti S, Paye F, et al. Laparoscopic simultaneous resection of colorectal primary tumor and liver metastases: a propensity score matching analysis. Surg Endosc 2016;30:1853-62. 
99. Untereiner X, Cagniet A, Memeo R, Tzedakis S, Piardi T, et al. Laparoscopic hepatectomy versus open hepatectomy for colorectal cancer liver metastases: comparative study with propensity score matching. Hepatobiliary Surg Nutr 2016;5:290-9.

100. Komatsu S, Brustia R, Goumard C, Perdigao F, Soubrane O, et al. Laparoscopic versus open major hepatectomy for hepatocellular carcinoma: a matched pair analysis. Surg Endosc 2016;30:1965-74.

101. Martinez-Cecilia D, Cipriani F, Shelat V, Ratti F, Tranchart H, et al. Laparoscopic versus open liver resection for colorectal metastases in elderly and octogenarian patients: a multicenter propensity score based analysis of short- and long-term outcomes. Ann Surg 2017;265:1192-200.

102. Sotiropoulos GC, Machairas N, Kostakis ID, Stamopoulos P, Charalampoudis P, et al. Early experience in starting a laparoscopic liver resection program in greece. JSLS 2017;21:e2016.

103. Peng L, Xiao J, Liu Z, Zhu J, Wan R, et al. Laparoscopic left-sided hepatectomy for the treatment of hepatolithiasis: a comparative study with open approach. Int J Surg 2017;40:117-23.

104. Chen J, Li H, Liu F, Li B, Wei Y. Surgical outcomes of laparoscopic versus open liver resection for hepatocellular carcinoma for various resection extent. Medicine (Baltimore) 2017;96:e6460.

105. Yu YD, Kim KH, Jung DH, Namkoong JM, Yoon SY, et al. Robotic versus laparoscopic liver resection: a comparative study from a single center. Langenbecks Arch Surg 2014;399:1039-45.

106. Jang EJ, Kim KW. Early experience of laparoscopic liver resection: a single institution experience with 37 consecutive cases. Ann hepato-biliary-pancreatic Surg 2019;23:115-2.

107. Cipriani F, Ratti F, Cardella A, Catena M, Paganelli M, et al. Laparoscopic versus open major hepatectomy: analysis of clinical outcomes and cost effectiveness in a high-volume center. J Gastrointest Surg 2019;23:2163-73.

108. Chen TH, Yang HR, Jeng LB, Hsu SC, Hsu CH, et al. Laparoscopic liver resection: experience of 436 cases in one center. J Gastrointest Surg 2019;23:1949-56.

109. Cipriani F, Alzoubi M, Fuks D, Ratti F, Kawai T, et al. Pure laparoscopic versus open hemihepatectomy: a critical assessment and realistic expectations - a propensity score-based analysis of right and left hemihepatectomies from nine European tertiary referral centers. J Hepatobiliary Pancreat Sci 2020;27:3-15.

110. Nomi T, Fuks D, Kawaguchi Y, Mal F, Nakajima Y, et al. Learning curve for laparoscopic major hepatectomy. Br J Surg 2015;102:796804.

111. Cheek SM, Geller DA. The learning curve in laparoscopic major hepatectomy: what is the magic number? JAMA Surg 2016;151:929.

112. Brown KM, Geller DA. What is the learning curve for laparoscopic major hepatectomy? J Gastrointest Surg 2016;20:1065-71.

113. Halls MC, Alseidi A, Berardi G, Cipriani F, Van der Poel M, et al. A comparison of the learning curves of laparoscopic liver surgeons in differing stages of the IDEAL paradigm of surgical innovation: standing on the shoulders of pioneers. Ann Surg 2019;269:221-8.

114. Tsilimigras DI, Moris D, Vagios S, Merath K, Pawlik TM. Safety and oncologic outcomes of robotic liver resections: a systematic review. J Surg Oncol 2018;117:1517-30.

115. Lin NC, Nitta H, Wakabayashi G. Laparoscopic major hepatectomy: a systematic literature review and comparison of 3 techniques. Ann Surg 2013;257:205-13.

116. Kasai M, Cipriani F, Gayet B, Aldrighetti L, Ratti F, et al. Laparoscopic versus open major hepatectomy: a systematic review and metaanalysis of individual patient data. Surgery 2018;163:985-95.

117. Packiam V, Bartlett DL, Tohme S, Reddy S, Marsh JW, et al. Minimally invasive liver resection: robotic versus laparoscopic left lateral sectionectomy. J Gastrointest Surg 2012;16:2233-8.

118. Winter JM, Talamini MA, Stanfield CL, Chang DC, Hundt JD, et al. Thirty robotic adrenalectomies: a single institution's experience. Surg Endosc 2006;20:119-24.

119. Barbash GI, Glied SA. New technology and health care costs--the case of robot-assisted surgery. N Engl J Med 2010;363:701-4.

120. Ho C, Tsakonas E, Tran K, Cimon K, Severn M, et al. Robot-assisted surgery compared with open surgery and laparoscopic surgery: clinical effectiveness and economic analyses [Internet]. Ottawa (ON): Canadian Agency for Drugs and Technologies in Health; 2011. 